\title{
PENURUNAN FUNGSI KOGNITIF DAPAT MENURUNKAN INDEKS MASSA TUBUH LANSIA DI PSTW WILAYAH DKI JAKARTA
}

\author{
Jayanti Indah Layla*, Dwi Nurviyandari Kusuma Wati \\ Fakultas Ilmu Keperawatan Universita Indonesia, Depok 16424, Indonesia \\ *E-mail: jayantilayla@gmail.com
}

\begin{abstract}
Abstrak
Proses penuaan dapat menyebabkan penurunan fungsi kognitif. Lansia dengan penurunan fungsi kognitif mengalami peningkatan metabolisme yang dapat menyebabkan malnutrisi. Penelitian ini bertujuan untuk mengetahui hubungan fungsi kognitif dengan indeks massa tubuh lansia di Panti Sosial Tresna Werdha wilayah DKI Jakarta. Desain penelitian yang digunakan adalah cross sectional dengan melibatkan 98 lansia yang dipilih melalui proportional dan simple random sampling. Fungsi kognitif dinilai dengan menggunakan kuesioner Mini Mental State Examination, sedangkan status gizi dinilai dengan menggunakan indeks massa tubuh. Hasil penelitian ini menunjukkan bahwa terdapat hubungan yang signifikan antara fungsi kognitif dan indeks massa tubuh $(\mathrm{r}=0,550 ; \mathrm{p}=0,0001 ; \alpha=0,05)$. Pemberi pelayanan di panti perlu memiliki keterampilan khusus untuk meningkatkan status gizi pada lansia dengan penurunan kognitif.
\end{abstract}

Kata kunci: fungsi kognitif, indeks massa tubuh, lingkar lengan atas, Mini Mental State Examination, Panti Sosial Tresna Werdha

\begin{abstract}
Cognitive Function Decline can Reduce The Body Mass Index of Elderly in Nursing Home. Aging process affects the decline of the cognitive function. Elderly with cognitive decline may have increased metabolism that can cause of malnutrition. This study aimed to determine the relationship between cognitive function with body mass index of elderly at Panti Sosial Tresna Werdha in DKI Jakarta. The study design was cross sectional with 98 elders, as the samples, who were selected through quota and simple random sampling. Cognitive function was assessed by using the MMSE instrument, while the nutritional status was assessed by using body mass index. The results of this study indicated that there was a significant correlation between cognitive function with body mass index $(r=0.550 ; p=0.0001 ; \alpha=0.05)$. Service providers in nursing home must have certain skills to improve the nutritional status of the elderly with cognitive decline.
\end{abstract}

Keywords: body mass index, cognitive function, MMSE, Panti Sosial Tresna Werdha

\section{Pendahuluan}

Penurunan fungsi kognitif yang terjadi pada lansia dapat mengganggu aktivitas makan. Lansia dengan penurunan kognitif dapat lupa dengan cara makan, tidak mengenali makanan, kesulitan melepaskan penutup piring dan pembungkus, kesulitan mengunyah dan menelan (Amella, 2007). Ketidakadekuatan intake nutrisi sering terjadi pada lansia dengan penurunan kognitif karena hilangnya kesadaran terhadap kebutuhan makan, menurunnya keman- dirian dalam makan, agnosia, apraxia, dan munculnya gangguan perilaku (Ebersole, Hess, Touhy, \& Jett, 2014).

Lansia dengan penurunan kognitif dapat mengalami kesulitan untuk berkomunikasi dengan orang lain saat mereka lapar dan membutuhkan bantuan untuk makan (Amella, 2007). Masalah lainnya yang dapat mengurangi nafsu makan seperti nyeri, efek obat, mual, buruknya kesehatan gigi dan mulut, serta diet khusus juga dapat memengaruhi asupan oral lansia 
dengan penurunan kognitif yang kurang mampu untuk memahami dan mengatasi masalah tersebut (Amella, 2007). Kehilangan berat badan biasanya sering menjadi perhatian penting pada lansia dengan demensia tahap akhir (Ebersole, et al., 2014).

Beberapa penelitian sebelumnya menunjukkan bahwa lansia dengan penurunan kognitif lebih rentan mengalami malnutrisi. Hasil penelitian Zekry, et al. (2008) menyebutkan bawa kelompok lansia dengan demensia memiliki skor Mini Nutritional Assessment dan Body Mass Index paling rendah jika dibandingkan dengan kelompok lansia dengan gangguan kognitif ringan dan fungsi kognitif normal. Penelitian lainnya dilakukan oleh Khater dan Abouelezz (2011) yang menunjukkan bahwa kelompok lansia dengan gangguan kognitif ringan lebih banyak mengalami gizi kurang disbanding kelompok lansia dengan fungsi kognitif normal. Kemudian, hasil penelitian Boscatto, Duarte, Coqueiro, dan Barbosa (2013) juga menunjukkan bahwa fungsi kognitif berhubungan positif dengan status gizi. Bedasarkan uraian di atas, penelitian ini melihat adanya hubungan fungsi kognitif dengan indeks massa tubuh lansia yang tinggal di Panti Sosial Tresna Werdha (PSTW) wilayah DKI Jakarta.

\section{Metode}

Desain penelitian yang digunakan dalam penelitian ini adalah cross sectional jenis anlitik korelasi. Desain tersebut digunakan untuk mengetahui hubungan fungsi kognitif dengan indeks massa tubuh lansia di Panti Sosial Tresna Werdha (PSTW) di wilayah DKI Jakarta.

Jumlah sampel pada penelitian ini adalah 98 responden yang dipilih dengan menggunakan cara proportional dan simple random sampling. Kriteria inklusi meliputi lansia yang dapat berkomunikasi dengan bahasa Indonesia dan berdiri pada timbangan injak.

Persetujuan etik penelitian telah diberikan oleh dosen pembimbing. Persetujuan izin penelitian juga telah diberikan oleh Pihak fakultas dan Badan Pelayanan Terpadu Satu Pintu DKI Jakarta. Kemudian peneliti melakukan pengambilan data dengan cara membacakan kuesioner kepada setiap responden. Kuesioner tersebut terdiri dari dua bagian yakni pertanyaan data demografi dan pertanyaan Mini Mental State Examination. Hasil uji validitas kuesioner MMSE pada 30 responden menunjukkan bahwa terdapat dua pertanyaan yang tidak valid dengan nilai $r=0,357$ dan 0,102 sehingga peneliti melakukan modifikasi terhadap kedua pertanyaan tersebut. Hasil uji reliabilitas memperoleh nilai Cronbach's Alpha 0,763 . Selain itu, pengambilan data juga dilakukan dengan mengukur panjang depa dan berat badan.

Analisis univariat digunakan untuk memperoleh gambaran distribusi usia, jenis kelamin, status perkawinan, pendidikan terakhir, riwayat penyakit, fungsi kognitif, dan indeks massa tubuh, sedangkan analisis bivariat digunakan untuk mengetahui hubungan fungsi kognitif dengan indeks massa tubuh lansia. Uji hipotesis yang digunakan adalah korelasi pearson dengan kemaknaan nilai $\mathrm{p}<0,05$.

\section{Hasil}

Tabel 1 menunjukkan bahwa sebagian besar lansia di PSTW berjenis kelamin perempuan $(59,2 \%)$, berada pada rentang usia 60-74 tahun $(74,5 \%)$, berstatus janda atau duda $(71,5 \%)$, memiliki riwayat pendidikan terakhir tidak sekolah $(64,3 \%)$, dan memiliki riwayat penyakit lain-lain seperti hipertensi, asam urat, gastritis, dan dermatitis $(56,1 \%)$.

Hasil uji normalitas menunjukkan bahwa data yang berdistribusi normal dengan rerata 20 dan standar deviasi 6,718. Nilai rerata digunakan sebagai cut off point untuk mengaktegorikan fungsi kognitif. Hampir sebagian lansia mengalami penurunan fungsi kognitif. Pengkategorian IMT berdasar pada nilai normal IMT menurut Depkes RI (2005) dalam Fatmah (2010). 
Tabel 1. Distribusi Frekuensi Karakteristik Lansia

\begin{tabular}{lcc}
\hline \multicolumn{1}{c}{ Karakteristik } & (n) & \% \\
\hline Jenis Kelamin & 40 & 40,8 \\
Laki-laki & 58 & 59,2 \\
Perempuan & & \\
Usia & 73 & 74,5 \\
60-74 tahun & 23 & 23,5 \\
$75-90$ tahun & 2 & 2,0 \\
$>90$ tahun & & \\
Status Perkawinan & 16 & 16,3 \\
Tidak Menikah & 70 & 71,5 \\
Janda atau Duda & 12 & 12,2 \\
Menikah & & \\
Pendidikan Terakhir & 63 & 64,3 \\
Tidak tamat sekolah & 16 & 16,3 \\
Tamat SD & 9 & 9,2 \\
Tamat SMP & 10 & 10,2 \\
Tamat SMA & & \\
Riwayat Penyakit & 30 & 30,6 \\
Tidak memiliki riwayat penyakit & 30,1 \\
Stroke & 6 & 4,1 \\
Diabetes Mellitus & 4 & 2,0 \\
PPOK & 2 & 1,0 \\
Kanker & 1 & 56,1 \\
Lain-lain & 55 & \\
Fungsi Kognitif & & 46,9 \\
Normal & 46 & 53,1 \\
Penurunan & 52 & 48,0 \\
IMT & & \\
Gizi Kurang $\left(<18,5 \mathrm{~kg} / \mathrm{m}^{2}\right)$ & 45 & \\
Normal $\left(18,5-25 \mathrm{~kg} / \mathrm{m}^{2}\right)$ & 47 & \\
Gizi lebih $\left(>25 \mathrm{~kg} / \mathrm{m}^{2}\right)$ & 6 & \\
\hline
\end{tabular}

Tabel 2. Hubungan Fungsi Kognitif dengan Status Gizi Lansia berdasarkan Indeks Massa Tubuh

\begin{tabular}{cccc}
\hline Variabel & Mean & Standar Deviasi & r/ $\mathbf{p}$ \\
\hline Fungsi Kognitif & 20 & 6,718 & $0,550 /$ \\
IMT & 19,27 & 4,1822 & $0,0001^{*}$
\end{tabular}

$(* \mathrm{p}=0,0001 ; \alpha=0,05)$

Hampir setengah dari total lansia mengalami status gizi kurang.

Hasil analisis bivariat pada Tabel 2 menunjukkan bahwa terdapat hubungan fungsi kognitif dengan indeks massa tubuh lansia dengan nilai p sebesar $0,0001(\alpha=0,05)$.

\section{Pembahasan}

Hasil penelitian ini menunjukkan bahwa terdapat hubungan fungsi kognitif dengan indeks massa tubuh lansia sebagai salah satu pengukuran status gizi. Hal ini sejalan dengan beberapa hasil penelitan sebelumnya. Penelitian 
Boscatto, et al. (2013) pada 134 lansia dengan usia antara 80 sampai 100 tahun yang tinggal di masyarakat negara Brazil menunjukkan bahwa fungsi kognitif berhubungan positif dengan status gizi. Penelitian lainnya oleh El Zoghbi, et al. (2013) pada lansia yang tinggal di institusi negara Lebanon menunjukkan bahwa terdapat hubungan positif yang signifikan antara skor MMSE dan skor MNA. Adanya kesamaan ini dapat disebabkan terganggunya aktivitas makan pada lansia dengan penurunan fungsi kognitif. Kegiatan makan memerlukan kemampuan kognitif untuk mengambil keputusan terhadap jenis dan kuantitas makanan (Dovey, 2010 dalam Laguna \& Chen, 2015). Lansia dengan penurunan kognitif dapat lupa dengan cara makan, tidak mengenali makanan, kesulitan melepaskan penutup piring dan pembungkus makanan (Amella, 2007).

Lansia dengan gangguan kognitif juga dapat mengalami ketidakadekuatan intake nutrisi. Hal tersebut disebabkan oleh hilangnya kesadaran terhadap kebutuhan makan, menurunnya kemandirian dalam makan, agnosia, apraxia, dan gangguan perilaku yang dialami oleh lansia dengan gangguan kognitif (Ebersole, et al., 2014). Beberapa perubahan perilaku yang biasanya muncul seperti keluyuran, agitasi, gangguan tidur dan irama sirkandian, serta hiperaktivitas terutama pada malam hari dapat menyebabkan peningkatan pengeluaran energi pada lansia dengan gangguan fungsi kognitif (Martin \& Preedy, 2015). Sebuah penelitian menunjukkan adanya ketidakseimbangan pengeluaran energi dari aktivitas fisik dengan asupan energi pada klien Alzheimer's Disease (Poehlman \& Dvorak, 2000).

Lansia dengan gangguan kognitif juga sering mengalami kesulitan berkomunikasi dengan orang lain. Kesulitan tersebut dapat terjadi saat lansia lapar dan membutuhkan bantuan untuk makan (Amella, 2007). Masalah lainnya yang dapat mengurangi nafsu makan pada lansia seperti nyeri, efek obat, mual, buruknya kesehatan gigi dan mulut, serta diet khusus dapat memengaruhi asupan oral lansia dengan gangguan kognitif yang kurang mampu untuk memahami dan mengatasi masalah tersebut (Amella, 2007). Menurut Ebersole et al. (2014) kehilangan berat badan biasanya sering menjadi perhatian penting pada lansia dengan demensia tahap akhir.

Selain itu, hasil penelitian ini juga dapat disebabkan karena meningkatnya basal metabolic rate (BMR) pada lansia dengan gangguan kognitif. Penelitian sebelumnya menunjukkan bahwa basal metabolic rate (BMR) pada pasien Alzheimer's Disease (salah satu jenis demensia) lebih meningkat dibandingkan individu yang memiliki fungsi kognitif normal (Wolf-Klein, et al., 1995 dalam Martin \& Preedy, 2015). Beberapa faktor yang dapat meningkatkan BMR pada klien dengan Alzheimer's Disease (AD) meliputi peningkatan penggunaan protein, perubahan fungsi tiroid, peningkatan akitivitas sistem saraf simpatik pada ganglia basal, dan kebocoran proton yang menyebabkan kerusakan mitokondria (Martin \& Preedy, 2015).

Keterbatasan dalam penelitian ini adalah kesulitan saat memvalidasi data karakteristik responden yang meliputi usia, status perkawinan, pendidikan terakhir, dan riwayat penyakit dengan menggunakan dokumen yang dimiliki oleh pihak panti. Dokumen riwayat sosial tidak seluruhnya disertai dengan bukti fotokopi kartu tanda penduduk responden. Kemudian terdapat pula dokumen riwayat sosial yang memiliki beberapa formulir pengkajian sosial dengan isian data yang berbeda. Beberapa dokumen rekam medik juga tidak memiliki data lengkap terkait riwayat penyakit responden.

Peneliti tidak melakukan tes gula darah dalam pengkajian riwayat penyakit diabetes mellitus. Peneliti tidak menggunakan kuesioner asli MMSE karena beberapa pertanyaan didalamnya telah dimodifikasi sesuai dengan hasil uji validitas dan kondisi lansia di PSTW. Peneliti juga merasa kesulitan dalam memvalidasi jawaban lansia saat pengkajian MMSE sehingga 
penilaian dilakukan apa adanya sesuai dengan jawaban yang diberikan oleh lansia.

\section{Kesimpulan}

Penelitian ini menghasilkan data gambaran karakteristik yang meliputi sebagian besar lansia berjenis kelamin perempuan, berada pada rentang usia 60-74 tahun (elderly), tidak sekolah, berstatus janda atau duda, dan memiliki riwayat penyakit lain-lain seperti hipertensi, asam urat, gastritis, serta dermatitis. Hasil penelitian ini menunjukkan bahwa hampir sebagian dari lansia di Panti Sosial Tresna Werdha mengalami penurunan fungsi kognitif. Mayoritas lansia dalam penelitian ini mengalami masalah status gizi kurang berdasarkan nilai indeks massa tubuh. Selain itu, pada penelitian ini juga didapat kesimpulan bahwa terdapat hubungan fungsi kognitif dengan indeks massa tubuh lansia.

Hasil penelitian ini dapat dijadikan sumber informasi bagi pemberi pelayanan di panti dan perawat gerontik agar dapat meningkatkan keterampilan dalam memberi intervensi terkait masalah kognitif maupun status gizi pada lansia. Kemudian, hasil penelitian ini juga dapat dijadikan data dasar dalam mengembangkan penelitian selanjutnya $(\mathrm{JH}, \mathrm{AYN}$, $\mathrm{TN})$.

\section{Referensi}

Amella, B.E.J. (2007). Eating and feeding issues in older adults with dementia part I: Assessment. New York, 26 (1).

Boscatto, E.C., Duarte, Mde.F., Coqueiro, Rda.S., Barbosa, A.R. (2013). Nutritional status in the oldest elderly and associated factors. Revista da Associacao Medica Brasileira, 59 (1), 40-47. doi: 10.1590/S0104-423020 13000100010 .
Ebersole, P., Hess, P., Touhy, T.A., \& Jett, K. (2014). Ebersole \& Hess' toward healthy aging: Human needs \& nursing response (4th Ed.). United States of America: Elsevier, Inc.

El Zoghbi, M., Boulos, C., Amal, A. H., Saleh, N., Awada, S., Rachidi, S., ... Salameh, P. (2013). Association between cognitive function and nutritional status in elderly: A cross-sectional study in three institutions of Beirut-Lebanon. Geriatric Mental Health Care, 1 (4), 73-81. doi:10.1016/j. gmhc.2013.04.007.

Fatmah. (2010). Gizi Usia Lanjut. Jakarta: Erlangga.

Khater, M. S., \& Abouelezz, N. F. (2011). Nutritional status in older adults with mild cognitive impairment living in elderly homes in Cairo, Egypt. The Journal of Nutrition, Health \& Aging, 15 (2), 104-8. http://doi.org/10.1007/s12603-011-0021-9.

Laguna, L., \& Chen, J. (2015). The eating capability: constituents and assessments. Food Quality and Preference, 48, 345-358. http://doi.org/10.1016/j.foodqual.201 5.03.008.

Martin, Colin R \& Preedy, Victor R. (2015). Diet and nutrition in dementia and cognitive decline. United States of America: Elsevier Inc.

Poehlman, E.T., \& Dvorak, R.V. (2000). Energy expenditure, energy intake, and weight loss in Alzheimer disease. American Society for clinical Nutrition, 71 (2). 650-655. Diperoleh dari http://ajen.nutrition. org/content/71/2/650s.long.

Zekry, D., Herrmann, F.R., Grandjean, R., Meynet, M.P., Michel, J.P., Gold, G., \& Krause, K. H. (2008). Demented versus non-demented very old inpatients: The same comorbidities but poorer functional and nutritional status. Age and Ageing, 37 (1), 83-89. http://doi. org/10.1093/ageing/ afm132. 